\title{
Engaging in Product Development as Means to Understand the Basics of Design
}

\author{
Sergio Rizzuti and Luigi De Napoli $\left.{ }^{(}\right)$ \\ DIMEG, University of Calabria, Ponte Pietro Bucci 46/C, 87036 Rende, CS, Italy \\ luigi.denapoli@unical.it
}

\begin{abstract}
Teaching product design is not a trivisal task. Considering the experience done along 20 years of teaching at master level class in mechanical engineering it is possible to take stock. The model followed is Project-Based Learning and this method can be licensed as the model that gives greater satisfaction to all attendees. Students give high score to the survey organized by university at the end of the course to assess didactic validity. Also, teachers have many stimuli when discussing with students the activities proposed. The course is based on the development of an industrial product that solves a problem, eventually posed by industry or emerged by customers. Based on the course schedule, the different phases of product development put in evidence the steps that require divergent thinking and those where it is necessary to employ convergent thinking. A case study allows explaining all the phases of product design.
\end{abstract}

Keywords: Project-Based Learning · Project-Based Pedagogy $\cdot$ Product design and development $\cdot$ Integration of design methodologies

\section{Introduction}

Design education is an experiential path on which students should be engaged in having the development of a product, as main task. After 20 years of teaching on such a matter, present authors said explicitly that there is no other method for students to understand the basis of design. As underlined by Dym, Agogino et al. [1] Project-Based Learning is the most-favored pedagogic model for teaching design. Discussion on Project-Based Learning (PBL) started on the basis of the Aalborg experiment, when the University was established in 1974. Still now Aalborg University is organized on such a method [2] and PBL is the pedagogical paradigm used in all courses organization. PBL's main assumption is the workgroup, as a means by which a set of people are involved in a discussion on a problem and searching for solutions to that problem. To find solution to problems is here focused on the engineering context, since the knowledge that students learned along with their course of study converges towards engineering solutions. The course in which students are asked to find a solution to a problem is placed in the second year of the Master's Degree in Mechanical Engineering and the name is Product Design and Development. As already reported in the past [3], the course is focused on the development of a product, considered as an engineering solution to a problem. After the 
definition of the problem to be solved, proposed by industry or emerged as a relevant theme, perceived inside the class, a set of activities are scheduled along the semester on which all the attendees are involved, working typically in a team. The paper describes the general organization of the course and the underlying methodologies employed along with some pedagogical considerations. Furthermore, a case study is briefly reported to give an insight to the commitment requested to students, that in all course editions have always positively rated it, by an anonymous survey at the end of semester.

\section{Course Organization for Master Level}

The course is proposed in the last semester of the Master's Degree in Mechanical Engineering. This allows students to employ all the subjects they have studied and learned along with their course of study. The course of Product Design and Development is one of the few offered at UNICAL (University of Calabria), that employs the teamwork as condition to attend it. Only marginally this is due to avoid the terribly amount of work, in term of deliverables, to be done by one person alone. The real motivation to promote teamwork is emphasized by problem solving and decision making tasks, which originates in all phases of the design work. Further it is important to push students towards improving quality of communication and consciousness of their own potentialities. The articulation of the course provides a set of activities that are classified into three learning-induced causes: instructor-directed learning; team-directed learning and individual self-directed learning [4]. During the 14 weeks of the semester, every week the activities are scheduled with two hours of lecture and two hours of teamwork in classroom on different days and at least eight hours of homeworking (in team and/or alone).

\subsection{Questioning}

At the basis of product design, or design in general, there is the need to understand the actual questions that a design solution would try to solve. This phase cannot be performed as individual activity. Students are not able to explore all the aspects visible and/or not visible behind a problem. Surely, well-experienced designers are able to investigate alone all the aspects often hidden behind a problem. A lot of heuristics is required to identify the true factors, discarding all the things not required or confusing. The problem clarification is generally performed by investigating on customer needs and functional decomposition.

\subsection{Divergent Thinking and Convergent Thinking}

In the last decades, the design practice has been analyzed and codified to make it an applicable approach in various areas. An important variation is design thinking [5, 6]. This may be summarized as a series of phases, which may seem chaotic at certain moments, that is resolved naturally passing from divergent thinking to the convergent thinking. Divergent thinking involves the typical creative phases in which alternatives are created, sometimes in the presence of more or less planned stimuli. Convergent thinking covers 
the phases in which analyzes are carried out and choices are synthesized. In Divergent steps, the previously assimilated knowledge represents the support layer. Therefore, students move from problem framing and diagnosis [7] to a process of exploration of needs and possible solutions starting from extensive questioning. Convergent steps, on the other hand, allow making the right choices with the aid of engineering knowledge. According to this scheme and working in team, sometimes supported by the teacher, interesting results may be obtained in a product design process. In the timetable shown in Table 1 it can be seen how in each phase of the design process, divergent and convergent approaches are identified. In the Table these are marked there with the symbols $(<)$ or $(>)$. The decades of experience in teaching product design has led the authors to identify and continuously update the most suitable practices and tools, also referring to the literature [8-13]. Lectures are delivered in order to illustrate methods and tools for stimulating and fostering the divergent phases. Furthermore, teachers introduce the most suitable methods to manage the convergent thinking in order to orient students towards an acceptable design solution [14]. For this purpose, they encourage students to resume those basics that they have acquired during their studies, sometimes integrating them.

\subsection{Pedagogical Aspects of Teaching Design by PBL}

At the early editions of the course, it was almost a gamble to organize a design activity on something that was not already designed. In the beginning, the starting point was to decide which kind of device one people would have been liked to design and a design process would be started with few variations, i.e., in terms of dimension or operation condition or productivity. Design activity consisted of an ordered sequence of steps, with few feedbacks, to converge towards a defined solution. The change of paradigm emerged when a problem was assigned instead.

A lot of discussion about the investigation around the problem would have required the need of more people involved in the process because one person alone would have been fruitless. During the course evolution over the years, according to the phases summarized in Table 1, students' aggregation in team came as a spontaneous requirement. And the optimal number of the team, for this class, has been settled around three elements per group (minimum two and maximum four). It was recognized that, generally, the workload during homework activity seems to be distributed equally among the team members. At the end of the product development process, to attend the exam students must write a mandatory essay in which all the steps followed are reported and discussed. This part can be written collegially or as a collage of many parts each one assigned to a team component. The exam is passed after a meeting in which all teams show their own product. A certain time (typically $1 / 2 \mathrm{~h}$ ) is assigned to each project and every student talks about some topics. This part is necessary to verify either the level of agreement among team members and the ability of each one. A second part is dedicated to an individual exam in which each student must answer on the complementary topics he/she did not treat previously. The project assessment is a sort of combination of the ranking of the project discussion (2/3) and the individual skill (1/3). Basically the way in which the problems have been faced and solved are assessed, instead of the product itself. Also when the theme is proposed by firms, the pedagogical aspects are considered as more relevant. 
Table 1. Timetable of the course lectures.

\begin{tabular}{|c|c|c|c|}
\hline Topic & Week & Lecture & $\begin{array}{c}\text { Convergent }(>) \\
\text { VS } \\
\text { Divergent }(<) \\
\end{array}$ \\
\hline \multirow{3}{*}{$\begin{array}{l}\text { 1. Clarify the } \\
\text { task }\end{array}$} & 1 & $\begin{array}{l}\text { The nature of design and the need for sys- } \\
\text { tematic approaches. }\end{array}$ & - \\
\hline & 2 & $\begin{array}{l}\text { The steps of product design and develop- } \\
\text { ment process. The product life cycle. }\end{array}$ & - \\
\hline & 3 & $\begin{array}{l}\text { Identification of market opportunity. Identi- } \\
\text { fication of customer needs; product plan- } \\
\text { ning; the requirement list. }\end{array}$ & $<$ \\
\hline \multirow{3}{*}{$\begin{array}{l}\text { 2. Conceptual } \\
\text { design }\end{array}$} & 4 & $\begin{array}{l}\text { The functional approach to design; the } \\
\text { functional net: clustered graph and function } \\
\text { tree. }\end{array}$ & $<$ \\
\hline & 5 & $\begin{array}{l}\text { Concept generation: search internally, indi- } \\
\text { vidually and in-group; externally activities. } \\
\text { The design creativity. }\end{array}$ & $<$ \\
\hline & 6 & $\begin{array}{l}\text { Concept selection. Matrix of relative and } \\
\text { absolute importance: screening and scoring. }\end{array}$ & $>$ \\
\hline \multirow{5}{*}{$\begin{array}{l}\text { 3. Embodi- } \\
\text { ment }\end{array}$} & 7 & Product architecture and product structure. & $<>$ \\
\hline & 8 & $\begin{array}{l}\text { Introduction to DSM (Design Structure } \\
\text { Matrix) }\end{array}$ & $>$ \\
\hline & 9 & Axiomatic design and design matrix. & $><$ \\
\hline & 10 & $\begin{array}{l}\text { DfM (Design for Manufacturing) and DfA } \\
\text { (Design for Assembly). }\end{array}$ & $<>$ \\
\hline & 11 & DfE (Design for Environment). & $<>$ \\
\hline \multirow{3}{*}{$\begin{array}{l}\text { 4. Detail de- } \\
\text { sign }\end{array}$} & 12 & $\begin{array}{l}\text { Robust Design (Taguchi method) and } \\
\text { ANOVA. }\end{array}$ & $>$ \\
\hline & 13 & $\begin{array}{l}\text { House of Quality. Customer satisfaction } \\
\text { (Kano model). }\end{array}$ & $><$ \\
\hline & 14 & $\begin{array}{l}\text { Detail design and the geometric quality of } \\
\text { the industrial products }\end{array}$ & $>$ \\
\hline
\end{tabular}

\section{Case Study}

The 2019 edition of the course proposed the theme "Transporting liquids for mediumterm excursions maintaining the temperature". The final product proposed has been a canteen. One of such products can be seen in Fig. 1, that has been also proposed by a rapid prototyping process (FDM). The theme was decided by students after some time on which many alternatives were arranged. The theme has been particularly relevant in 2019 considering that the movement "Friday for future" demanded the governments on planet survival. "NOplanetB" [15] has been, and is still now, the slogan that explains the crude reality for the battle against climatic changes. After a research on such matter, Brainwriting [16] allowed students to generate an average of 10 ideas per team. The employment of divergent thinking was applied by the student for the first time along with their curriculum and the emotional trouble reported in the literature $[17,18]$ was confirmed. A lot of works followed this first phase and a set of methods, employed for selection, comparison, trade-off, optimization, and finally, the drafts, complete with the checks on Geometric Dimensioning and Tolerancing, allows to give birth to the device. 


\section{Discussion}

Over the years, the experience matured by teachers convinced them of the opportunity to emphasize the importance of teamwork. The team is considered the nucleus on which all elaborations must be referred. The people involved in a course of product design are many. Teacher, Students, Customer/s. The way in which they are related is at the basis of the goal of such kind of course: Teach to Design and above all Learn to Design. Indubitably a set of information must be transferred to students and a certain number of lectures are required. Many are the approaches proposed worldwide and it can be said that no one may solve completely all questions. It remains to teachers the selection of the methodologies more appropriate for the solution of a defined problem. Concerning Table 1, some topics could be treated only as information, considering that a particular problem probably does not require those methods. Immediately after each lecture, teamwork is required to verify if the theoretic introduced have been matured and well applied.

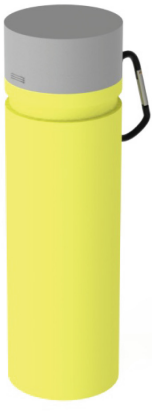

a)

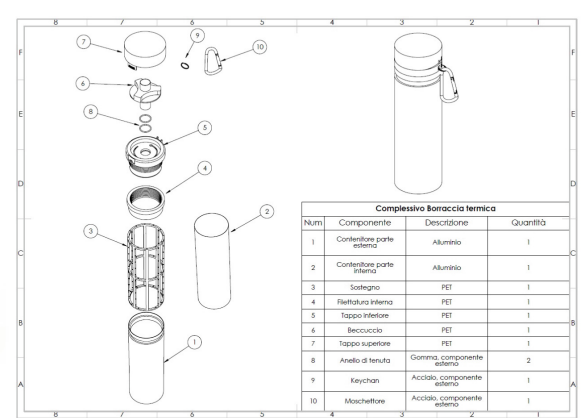

b)

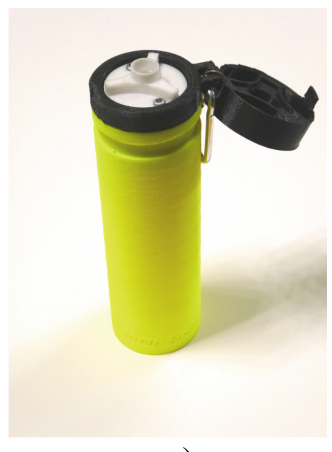

c)

Fig. 1. First prototype of the canteen: a) 3D model; b) exploded draft; c) 3D printing prototype.

Discussions inside the design team allow students to clarify if their understanding is well established. Teamwork is essential to search for alternative products already present on the market, for consulting of patents and literature. It is fundamental for organizing interviews with potential customers of the proposed device. Conceptual design is mandatory for the team, where brainwriting methodology is applied. In brief, many phases of design must be done inside the team, because the amount of work must be shared among pairs and performed with the same degree of consciousness. Individual work is also natural along the semester because each team component continues to think all aspects of the problem also when he/she remains alone. Each team member is involved in the creative process and it is not clear when the bulb start lighting for him/her, as Wallas described in the incubation phase of his model of the creative process [19]. Typically, not only during workshops. A designer looks like a lover that thinks to his/her love over and over again. Product design is a fascinating activity. Or one person is involved in it, or NOT. A designer cannot be considered a cold lover. Project-based design is a stimulating atmosphere that involves all attendees and produces a circulation of ideas. 
Teachers must also answer to subjects or solutions that they never thought and that can reveal new ways of solution.

\section{Conclusion}

The program of the course of Product Design and Development held at the University of Calabria can now be considered consistent and well arranged. Along the time new experiments have been tried and constantly students answered positively to the organization. The course completes student skillfulness at the end of their curriculum because the course is put in the second semester of the Master's Degree. Anyway, the strength's point is the organization of the work in teams. The discussion, the questioning, the sharing of tasks introduces a different way of solving problems, first of all, because all work must be generated, conceived, organized, shared, assessed. Not only during Divergent phases in which several points of view must be considered but also in Convergent phases where the right criteria must be chosen in order to validate the promising ideas. The approach Project-Based Learning is ideal for Product design teaching. Moreover, it has been noticed over the years how this type of teaching engages students to such an extent that, in general, all of them pass the exam on the first attempt and with a very high mark.

\section{References}

1. Dym, C.L., Agogino, A.M., Eris, O., Frey, D.D., Leifer, L.J.: Engineering design thinking, teaching and learning. J. Eng. Educ. 94(1), 103-119 (2005)

2. https://www.en.aau.dk/education/problem-based-learning. Accessed 28 Jan 2020

3. Rizzuti, S.: A coherent teaching program for a course of product design at master degree level. In: XXIII International Conference on Graphic Engineering, Madrid, 19-21 June 2013, pp. 1-5 (2013). ISBN 978-84-695-7930-5

4. Larsen, S.B., Kjaersgaard, N.C., Bigum, P.V., Jacobsen, P.: Understanding how students learn in project-based courses: a review of literature. Paper presented at the 47th SEFI Annual Conference, Budapest, Hungary. DTU Library (2019)

5. Brown, T.: Design thinking. Harvard Bus. Rev. 86(6), 84-92 (2008)

6. Razzouk, R., Shute, V.: What is design thinking and why is it important? Rev. Educ. Res. 82(3), 330-348 (2012)

7. Jackson, N.J., Buining, F.: Enriching problem-based learning through design thinking. In: Barrett, T., Moore, S. (eds.) New Approaches to Problem-Based Learning: Revitalising Your Practice in Higher Education, pp. 269-293. Routledge, London (2010)

8. Otto, K.N., Wood, K.L.: Product Design: Techniques in Reverse Engineering and New Product Development. Prentice-Hall, Upper Saddle River (2001)

9. Taguchi, G., Chowdhury, S., Wu, Y.: Taguchi's Quality Engineering Handbook. Wiley, Hoboken (2005)

10. Suh, N.P.: Axiomatic Design: Advances and applications. Oxford University Press, Oxford (2001)

11. Ulrich, K.T., Eppinger, S.D.: Product design and development. McGraw-Hill, New York (2012)

12. Cross, N.: Engineering Design Methods, Strategies for Product Design. Wiley, Hoboken (2000) 
13. Pahl, G., Beitz, W., Feldhusen, J., Grote, K.H.: Engineering Design: A Systematic Approach. Springer, Heidelberg (2007)

14. Rizzuti, S., De Napoli, L.: ANOVA applied to the taguchi method: a new interpretation. In: Rizzi, C., Andrisano, A., Leali, F., Gherardini, F., Pini, F., Vergnano, A. (eds.) Lecture Notes in Mechanical Engineering. Springer, Cham (2020)

15. https://www.noplanetb.net/. Accessed January 2020

16. Rizzuti, S., De Napoli, L.: Proposal of a framework based on continuous brainwriting to expand mindfulness in concept generation. In: Rizzi, C., Andrisano, A., Leali, F., Gherardini, F., Pini, F., Vergnano, A. (eds.) Design Tools and Methods in Industrial Engineering, ADM 2019. Lecture Notes in Mechanical Engineering. Springer, Cham (2020)

17. Baruah, J., Paulus, P.B.: Collaborative creativity and innovation in education. In: Mullen C. (ed.) Creativity Under Duress in Education? Creativity Theory and Action in Education, vol. 3. Springer, Cham (2019)

18. Henriksen, D., Richardson, C., Mehta, R.: Design thinking: a creative approach to educational problems of practice. Thinking Skills Creativity 26, 140-153 (2017)

19. Wallas, G.: The art of thought. J. Cape, London (1926)

Open Access This chapter is licensed under the terms of the Creative Commons Attribution 4.0 International License (http://creativecommons.org/licenses/by/4.0/), which permits use, sharing, adaptation, distribution and reproduction in any medium or format, as long as you give appropriate credit to the original author(s) and the source, provide a link to the Creative Commons license and indicate if changes were made.

The images or other third party material in this chapter are included in the chapter's Creative Commons license, unless indicated otherwise in a credit line to the material. If material is not included in the chapter's Creative Commons license and your intended use is not permitted by statutory regulation or exceeds the permitted use, you will need to obtain permission directly from the copyright holder.

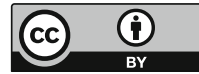

